8 Research Square

\title{
Assessment of Physico-Chemical Parameters and Heavy Metal of Drinking Water Samples from Some Iranian Universities and Surveyed the Efficacy of Several Water Purification Methods on Removal of Heavy Metal
}

Zeinab Rezaei

Ferdowsi University of Mashhad Faculty of Veterinary Medicine

Saeid Khanzadi

Ferdowsi University of Mashhad Faculty of Veterinary Medicine

\section{Ehsan Shamloo}

Neyshabur University of Medical Sciences

Amir Salari ( $\sim$ a-salari@um.ac.ir)

Ferdowsi University of Mashhad Faculty of Veterinary Medicine https://orcid.org/0000-0001-7553-0362

\section{Research Article}

Keywords: Physicochemical parameters, Heavy metals, Universities, Pollution, Purification Methods

Posted Date: January 6th, 2022

DOI: https://doi.org/10.21203/rs.3.rs-1226896/v1

License: (c) (i) This work is licensed under a Creative Commons Attribution 4.0 International License. Read Full License 


\section{Abstract}

Water quality is the most important factor for consumers because it has a significant impact on their health. So, monitoring and controlling water quality is of particular significance in different human communities such as universities. In this study, the physicochemical parameters such as turbidity, electrical conductivity, hardness, alkalinity, calcium and magnesium ions, and heavy metals including lead, cadmium, nickel, arsenic, and chromium in drinking water were determined in nine Iranian universities. Then, the efficacy of several treatment methods was evaluated in the removal of heavy metal, including the boiling process in two stages: 5 minutes boiling and 5 hours boiling and filtration process. The results revealed that the physicochemical quality of drinking water in all universities was appropriate. Hardness levels in drinking water samples of all universities were higher than the WHO standards. However, this parameter was lower than the national standard of Iran ( $500 \mathrm{mg} / \mathrm{l})$. Nevertheless, cadmium content was not detected in any samples, nickel content was below the permissible limit, and chromium content was below the permissible limit in all samples. However, its value was higher than the allowable limit in the university with a code of 6 . Lead content was higher than the limit in samples with codes 3, 5-1, and 5-4, and arsenic content was higher than the limit in samples with codes 6, 1-1, 1-2, and 2. Water purification methods, including boiling and water purifier, were satisfactory and significantly reduced pollutants. According to the present study, it is suggested to check drinking water quality in universities randomly, and the 5-minute boiling method can be recommended as a cost-effective solution for water purification.

\section{Introduction}

Water plays a vital role in human life, and water quality is one of the significant health issues affecting the health of the individual and society. Therefore, the World Health Organization (WHO) has identified one of the most important health indicators in developing countries: healthy water resources. Since the expansion of agricultural, industrial, and social developments has led to water pollution and degradation of water quality, and on the other hand, population growth has increased water consumption, periodic monitoring and quality control of water resources are inevitable [1-3]. Heavy metals are among serious challenges in drinking water resources and are a global concern due to their toxicity to human health and the environment. Accordingly, it is necessary to monitor these elements, especially in drinking water, constantly $[4,5]$. Exposure to heavy metals can cause skin disorders, respiratory cancer, depression, anemia, heart failure, reproductive disorders, decreased immunity, gastrointestinal disorders, and even death $[6,7]$. Nickel is one of the heavy metals abundant in the Earth's crust and is widely used in industry due to its physical and chemical properties resulting in environmental pollution [6]. Numerous studies have suggested that producing reactive oxygen and oxidative stress are action mechanisms of heavy metals such as arsenic, cadmium, lead, and chromium [5, 8]. Among the toxic metals, arsenic has been reported to be a concern for environmental and biological health and identified as a toxic element due to its influence on the sulfhydryl group [9, 10]. Other qualitative aspects of water include its physicochemical properties, which are very effective in the general acceptance of water [11, 12]. Hardness above $200 \mathrm{mg} / \mathrm{l}$ causes deposits in pipes and distribution systems as well as reducing water purification power. Furthermore, hardness less than $100 \mathrm{mg} /$ liter can cause corrosion [13]. The presence of minerals causes turbidity and organic matter suspended in water, and in most cases, microorganisms also attach to these compounds. Therefore, high turbidity and destroying the clear appearance of water, and consumer dissatisfaction can also cause gastrointestinal diseases $[14,15]$. Considering the importance of water health and hygiene, in recent years, water purifiers have become very common in various parts of the world, including the Middle East. Water purifiers include reverse osmosis devices and semi-industrial pre-treatment devices[16, 17]. Boiled water is recommended in most communities when poisoning epidemics occur [18]. On the other hand, the process of boiling water can affect its quality [19]. So, due to the pivotal role of water in human life and since water hygiene can affect the health of the university community as a centralized place, in this study, we monitored the physicochemical quality of drinking water in major universities in Iran. Continuation of the efficiency of two water treatment techniques, including boiling water in two stages of 5 minutes and 5 hours, and pre-treatment of water quality was evaluated in this study.

\section{Materials And Methods}

\section{Sample Collection and preparation}

The present study is a cross-sectional survey investigating the number of physicochemical pollutants and heavy metals content in the urban water distribution network of nine major universities in Iran. Forty samples of drinking water were analyzed, and plastic 1-liter containers were used to collect samples. These containers were thoroughly washed and dried with distilled water before filling with water samples. Then, the physicochemical parameters such as turbidity, electrical conductivity, hardness, alkalinity, calcium, and magnesium ions were analyzed according to the standard method.

\section{Measurement of heavy metals}

To prepare interface standard, $10 \mathrm{ml}$ of standard $1000 \mathrm{mg} / \mathrm{l}$ solutions of each element were transferred to a $100 \mathrm{ml}$ volumetric flask. Then, it was diluted with $100 \%$ nitric acid to a volume of $100 \mathrm{ml}$ and mixed well. The resulting solution had a concentration of $100 \mathrm{mg} / \mathrm{l}$ or $100 \mathrm{ppm}$ of the desired element. To measure each element in drinking water samples, the optimal wavelength was selected according to Table 1. Blank samples and standards were injected, and the standard curve was drawn. After calibrating the device for measurement, drinking water samples were analyzed by the ICP device (Inductively Coupled Plasma, model: SpectroAcrose-76004555, Made in Germany). 


\section{Water boiling}

To investigate the effect of boiling water process on the removal of heavy metals, samples were prepared in three replications of the desired drinking water. The boiling operation was performed in two stages of boiling for 5 minutes and 5 hours, then heavy metal of samples were analyzed.

\section{Pre-filtration of water}

A semi-industrial water purifier was installed on the inlet of consumer water, and then a sample of purified water was taken from the outlet and examined for heavy metal content. This device was made in Thailand by a Soft Water Company. This device includes three stages of pretreatment, two treatment pumps, two transformers, and four membranes of 100 gallons (Each membrane has 13 layers), and activated carbon.

Table 1

wavelengths (nanometers) used of the measured elements by ICP

\begin{tabular}{|lll|}
\hline Number & Heavy metals & Wavelength $(\boldsymbol{\lambda}(\mathrm{nm}))$ \\
\hline 1 & $\mathrm{As}$ & 189 \\
\hline 2 & $\mathrm{Ni}$ & 231 \\
3 & $\mathrm{Cr}$ & 205 \\
\hline 4 & $\mathrm{Cd}$ & 214 \\
\hline 5 & $\mathrm{~Pb}$ & 220 \\
\hline
\end{tabular}

\section{Statistical Analysis}

One-way analysis of variance (ANOVA) was performed, and the significant differences between the film properties were determined $(p<0.05)$ with Duncan's multiple range tests using the SPSS statistical analysis program (SPSS 21, SPSS Inc., Chicago, IL, USA).

\section{Result}

Table 2 is the summarized result of the level of heavy metals in samples taken from different places. Results of physico chemical analysis are presented in Table 3.

Table 2

Heavy metals $(\mu \mathrm{g} / \mathrm{I})$ in the drinking water $(\mathrm{N}=40)$

\begin{tabular}{|llllll|}
\hline Sampling location number & $\mathrm{AS}$ & $\mathrm{Ni}$ & $\mathrm{Cr}$ & $\mathrm{Cd}$ & $\mathrm{Pb}$ \\
\hline $1-1$ & $11.17 \pm 0.03$ & $\mathrm{BDL}$ & $\mathrm{BDL}$ & $\mathrm{BDL}$ & $\mathrm{BDL}$ \\
\hline $1-2$ & $11.18 \pm 0.06$ & $\mathrm{BDL}$ & $\mathrm{BDL}$ & $\mathrm{BDL}$ & $\mathrm{BDL}$ \\
\hline 2 & $9.64 \pm 0.06$ & $3.54 \pm 0.4$ & $\mathrm{BDL}$ & $\mathrm{BDL}$ & $8.45 \pm 0.7$ \\
\hline 3 & $8.5 \pm 0.05$ & $1.87 \pm 0.09$ & $5.31 \pm 0.07$ & $\mathrm{BDL}$ & $14.7 \pm 0.16$ \\
\hline 4 & $6.5 \pm 0.14$ & $\mathrm{BDL}$ & $1.81 \pm 0.04$ & $\mathrm{BDL}$ & $3.1 \pm 0.16$ \\
\hline $5-1$ & $\mathrm{BDL}$ & $\mathrm{BDL}$ & $0.06 \pm 0.0$ & $\mathrm{BDL}$ & $14.6 \pm 0.13$ \\
\hline 6 & $13.72 \pm 0.07$ & $4.62 \pm 0.1$ & $4.68 \pm 0.25$ & $\mathrm{BDL}$ & $3.87 \pm 0.04$ \\
\hline 7 & $\mathrm{BDL}$ & $1.82 \pm 0.0$ & $1.42 \pm 0.04$ & $\mathrm{BDL}$ & $4.7 \pm 0.03$ \\
\hline 8 & $\mathrm{BDL}$ & $\mathrm{BDL}$ & $\mathrm{BDL}$ & $\mathrm{BDL}$ & $9.04 \pm 0.15$ \\
\hline 9 & $7.5 \pm 0.08$ & $2.93 \pm 0.1$ & $86 \pm 0.21$ & $\mathrm{BDL}$ & $4.48 \pm 0.06$ \\
\hline $5-2$ & $\mathrm{BDL}$ & $\mathrm{BDL}$ & $\mathrm{BDL}$ & $\mathrm{BDL}$ & $1.88 \pm 0.06$ \\
\hline $5-3$ & $\mathrm{BDL}$ & $\mathrm{BDL}$ & $0.05 \pm 0.01$ & $\mathrm{BDL}$ & $1.97 \pm 0.02$ \\
\hline $5-4$ & $\mathrm{BDL}$ & $\mathrm{BDL}$ & $\mathrm{BDL}$ & $\mathrm{BDL}$ & $13.6 \pm 0.12$ \\
\hline BDL: Below Detection Limit, N: number of samples analyzed. & & & \\
\hline
\end{tabular}

As shown in Table 2, cadmium was not found in any of the samples. On the other hand, the highest amount of arsenic with an average of $13.72 \pm$ 0.07 in the university drinking water sample with code 6 and the lowest amount of this toxic metal in the university drinking water sample with code 4 with an average of $6.5 \pm 0.14$. Heavy metal chromium was not found in 5 samples of university water and in other samples its amount was 
below the standard. Lead was found in the drinking water of all universities except code one. Nickel was also not found in eight samples of drinking water from the surveyed universities. And its value in other samples was below the allowable limit.

Table 3

Physico chemical parameters

\begin{tabular}{|c|c|c|c|c|c|c|c|c|c|c|c|c|c|c|}
\hline Parameters & $1-1$ & $1-2$ & 2 & 3 & 4 & $5-1$ & $5-2$ & $5-3$ & $5-4$ & 6 & 7 & 8 & 9 & WHO \\
\hline $\mathrm{Mg}++(\mathrm{mg} / \mathrm{l})$ & $\begin{array}{l}23.9 \\
\pm \\
0.2\end{array}$ & $\begin{array}{l}34.6 \\
\pm 0.1\end{array}$ & $\begin{array}{l}63.9 \\
\pm \\
0.1\end{array}$ & $\begin{array}{l}30.24 \\
\pm 0.1\end{array}$ & $\begin{array}{l}13.62 \pm \\
0.98\end{array}$ & $\begin{array}{l}9 \pm \\
0.12\end{array}$ & $\begin{array}{l}7.3 \pm \\
0.14\end{array}$ & $\begin{array}{l}8.29 \\
\pm \\
0.13\end{array}$ & $\begin{array}{l}11.21 \\
\pm \\
0.61\end{array}$ & $\begin{array}{l}39.51 \\
\pm \\
0.56\end{array}$ & $\begin{array}{l}10.73 \\
\pm \\
0.19\end{array}$ & $\begin{array}{l}12.195 \pm \\
0.15\end{array}$ & $\begin{array}{l}28.50 \\
\pm \\
0.26\end{array}$ & 150 \\
\hline $\mathrm{Ca}++(\mathrm{mg} / \mathrm{l})$ & $\begin{array}{l}72.8 \\
\pm \\
0.7\end{array}$ & $\begin{array}{l}79.2 \\
\pm 0.3\end{array}$ & $\begin{array}{l}83.4 \\
\pm \\
0.2\end{array}$ & $\begin{array}{l}52.8 \pm \\
0.52\end{array}$ & $\begin{array}{l}62.4 \pm \\
0.25\end{array}$ & $\begin{array}{l}56 \pm \\
.15\end{array}$ & $\begin{array}{l}60 \pm \\
0.51\end{array}$ & $\begin{array}{l}58.4 \\
\pm \\
0.14\end{array}$ & $\begin{array}{l}53.6 \pm \\
0.15\end{array}$ & $\begin{array}{l}87.2 \\
\pm \\
0.75\end{array}$ & $\begin{array}{l}45.6 \\
\pm 0.7\end{array}$ & $\begin{array}{l}56 \pm \\
0.23\end{array}$ & $\begin{array}{l}43.2 \\
\pm \\
0.15\end{array}$ & 200 \\
\hline Alkality (mg/l) & $\begin{array}{l}167 \\
\pm \\
0.8\end{array}$ & $\begin{array}{l}141 \pm \\
0.12\end{array}$ & $\begin{array}{l}192 \\
\pm \\
0.7\end{array}$ & $\begin{array}{l}208 \pm \\
0.2\end{array}$ & $\begin{array}{l}170 \pm \\
0.36\end{array}$ & $\begin{array}{l}80 \pm \\
0.47\end{array}$ & $\begin{array}{l}73 \pm \\
0.27\end{array}$ & $\begin{array}{l}82 \pm \\
0.87\end{array}$ & $\begin{array}{l}75 \pm \\
0.21\end{array}$ & $\begin{array}{l}226 \pm \\
0.89\end{array}$ & $\begin{array}{l}208 \pm \\
0.93\end{array}$ & $\begin{array}{l}164 \pm \\
0.31\end{array}$ & $\begin{array}{l}207 \pm \\
0.56\end{array}$ & 500 \\
\hline $\begin{array}{l}\text { Hardness } \\
(\mathrm{CaCO}(\mathrm{mg} / \mathrm{l}))\end{array}$ & $\begin{array}{l}280 \\
\pm \\
0.1\end{array}$ & $\begin{array}{l}340 \pm \\
0.18\end{array}$ & $\begin{array}{l}468 \\
\pm \\
0.6\end{array}$ & $\begin{array}{l}256 \pm \\
0.31\end{array}$ & $\begin{array}{l}212 \pm \\
0.34\end{array}$ & $\begin{array}{l}180 \\
\pm 0.52\end{array}$ & $\begin{array}{l}181 \pm \\
0.26\end{array}$ & $\begin{array}{l}178 \\
\pm \\
0.62\end{array}$ & $\begin{array}{l}183 \pm \\
0.16\end{array}$ & $\begin{array}{l}380 \pm \\
0.96\end{array}$ & $\begin{array}{l}158 \pm \\
0.74\end{array}$ & $\begin{array}{l}190 \pm \\
0.34\end{array}$ & $\begin{array}{l}108 \pm \\
0.12\end{array}$ & 100 \\
\hline $\begin{array}{l}\text { Turbidity } \\
\text { (NTU) }\end{array}$ & $\begin{array}{l}0.34 \\
\pm \\
0.4\end{array}$ & $\begin{array}{l}0.28 \pm \\
0.14\end{array}$ & $\begin{array}{l}0.37 \\
\pm \\
0.3\end{array}$ & $\begin{array}{l}0.27 \pm \\
0.36\end{array}$ & $\begin{array}{l}0.78 \pm \\
0.23\end{array}$ & $\begin{array}{l}0.46 \\
\pm .04\end{array}$ & $\begin{array}{l}0.31 \pm \\
0.65\end{array}$ & $\begin{array}{l}0.36 \\
\pm \\
0.03\end{array}$ & $\begin{array}{l}0.29 \pm \\
0.002\end{array}$ & $\begin{array}{l}0.24 \\
\pm \\
0.03\end{array}$ & $\begin{array}{l}0.50 \pm \\
0.02\end{array}$ & $\begin{array}{l}0.61 \pm \\
0.02\end{array}$ & $\begin{array}{l}0.62 \\
\pm \\
0.02\end{array}$ & 5 \\
\hline $\begin{array}{l}\text { Conductivity } \\
(\mu \mathrm{s} / \mathrm{cm})\end{array}$ & $\begin{array}{l}720 \\
\pm \\
0.5\end{array}$ & $\begin{array}{l}1083 \\
\pm \\
0.25\end{array}$ & $\begin{array}{l}666 \\
\pm \\
0.25\end{array}$ & $\begin{array}{l}1051 \pm \\
0.87\end{array}$ & $\begin{array}{l}664 \pm \\
0.87\end{array}$ & $\begin{array}{l}431 \pm \\
0.26\end{array}$ & $\begin{array}{l}372 \pm \\
0.32\end{array}$ & $\begin{array}{l}413 \pm \\
0.93\end{array}$ & $\begin{array}{l}402 \pm \\
0.98\end{array}$ & $\begin{array}{l}917 \pm \\
0.99\end{array}$ & $\begin{array}{l}326 \pm \\
0.87\end{array}$ & $\begin{array}{l}433 \pm \\
0.98\end{array}$ & $\begin{array}{l}1365 \\
\pm \\
0.98\end{array}$ & - \\
\hline
\end{tabular}

The physicochemical properties of drinking water of the studied universities are presented in Table 3 . Comparing the obtained results with the standard of the World Health Organization shows that most of the studied parameters are within the standard and there is only this discrepancy in the case of hardness. The results showed that the hardness in all samples was higher than the desired level of the World Health Organization but the amount of hardness was less than the recommended amount of the Iranian national standard $(500(\mathrm{mg} / \mathrm{l}))$.

The efficiency of water treatment methods is shown in Figures 1 to 5 below.

The results of the study of the efficiency of treatment methods on the removal of toxic metal contaminants showed that the process of boiling water for 5 minutes can reduce the toxic metal arsenic in water by about $45.27 \%$ and boiling for 5 hours showed a decrease of about $51.5 \%$.

The results of reducing the amount of nickel under different processes showed that boiling water for 5 hours could have a greater reduction in the content of toxic metal nickel.

The results showed that after boiling water at both different times, the amount of lead was undetectable.

The results of the study of the amount of toxic metal chromium in water after treatment processes showed that due to the fact that the initial amount of metal in the control sample was less than the standard and insignificant, therefore it was undetectable in all three treatment processes.

The results showed that the content of cadmium toxic metal reached an undetectable range after the impact of three treatment processes.

\section{Discussion}

Water is one of every creature's basic needs, and without it, life will not exist. Drinking water and supplying the body with water containing salts and minerals are essential for the body [20]. However, the decrease or increase of some of these minerals lead to various problems and diseases. In the present study, the results of monitoring the physicochemical properties of water showed that most of the studied parameters are below the limit reported by the World Health Organization. Only the water hardness parameter in all samples is higher than the desired limit recommended by the World Health Organization. On the contrary, the permissible limit is $500 \mathrm{mg} / \mathrm{l}$ according to the national standard of Iran, showing that there is no problem. Besides, the turbidity parameter had a desirable value, and this issue can be raised about the popularity and quality of water [21]. Examination of heavy metals in drinking water samples of different universities showed that the number of metals was higher than the allowable limit (10 mg/l) in some samples [22]. The amount of toxic metal arsenic in the university with the codes 1-1, 1-2, and 6 is higher than the allowable level, and it is necessary to take the necessary measures to follow up the pollution and eliminate it. Previous studies indicate that due to the abundance and presence of more arsenic in the Earth's crust, the possibility of this metal's presence in groundwater and surface water sources is high. Therefore, reconsidering the source of drinking water should be a necessary measure to take [23]. It should be mentioned that cadmium was not found in any of the samples. Not detecting the toxic metal cadmium in water can also be related to the safety of water distribution pipes. On 
the other hand, sediments deposited on the inner body of the distribution pipes themselves are a barrier to releasing this metal into the water of the municipal network [24]. Numerous studies have been conducted on the quality of drinking water in Iran in different cities, revealing that other sources of drinking water supply are desirable in terms of safety and health except for a few cases [25]. Alidadi et al. investigated the concentration of heavy metals and fluorid in the drinking water network of Mashhad city [26, 27]. The results were similar in some of the heavy metal measurements. The amount of toxic lead metal in the drinking water samples of universities with codes $3,5-1$, and $4-5$ was higher than the allowable limit (10 mg/l). The presence of lead in drinking water can have several causes. It should also be borne in mind that the drinking water samples studied were collected from different parts of the country with different contexts and climatic conditions, which can justify the dispersion of the studied parameters. The present study results showed that the amount of chromium in all samples was below the standard limit ( $50 \mu \mathrm{g} / \mathrm{l}$ ). Also, the amount of nickel in all samples was reported below the standard limit, except in the samples with code 6, where the reported amount was declared higher than the allowable limit. Evaluating the effect of boiling processes on the content of heavy metals in water revealed that in the boiling for 5 minutes technique, compared to the boiling for 5 hours, almost the same amount of heavy metals were removed. Hence, it can be considered that boiling water for less amount of time and with less energy consumption can be a cost-effective and fast strategy for water purification. Also, comparing the efficiency of boiling methods with filtration shows that the reduction rate of toxic metals in the filtration method is less, providing the basis for further research.

Velayatzadeh et al. investigated the effect of household water purifiers on the concentration of metals in drinking water in Ahvaz city[28]. The results revealed that house water purifiers reduce heavy metals, which is similar to the results obtained from the present study [29, 30]. However, they will be valuable for removing heavy metals from drinking water. A review of previous studies on the content of heavy metals in the drinking water of different cities in Iran shows that no comprehensive study has been conducted on the quality of drinking water in universities as a centralized place[8,31]. Brief studies have also been conducted in the cities under study. Consequently, studying the quality of drinking water and its continuous monitoring is of utmost significance and can be an essential issue at the forefront of research.

\section{Conclusion}

The present study results showed that continuous monitoring of drinking water resources in centralized places such as universities is one of the necessities for maintaining consumers' health. If possible, with further studies, water purifiers can be used to make drinking water more palatable. It is also possible to improve the hygienic quality of water and prevent secondary contamination by using boiling for a short time (5 minutes).

\section{Declarations}

\section{Authors' Contributions}

Amir Salari, Saeid Khanzadi, and Zeinab Rezaei designed the study; Amir Salari and Zeinab Rezaei conducted the study, analyzed the data, and drafted the manuscript. All the authors read, revised, and approved the final manuscript.

\section{Conflicts of Interest}

None declared.

\section{Acknowledgments}

This article was extracted from a research project approved by the School of Veterinary Medicine at Ferdowsi University of Mashhad, Iran (code: 407242). Hereby, we extend our gratitude to the Student Welfare Fund, heads of the investigation Department of Nutrition, and Mashhad Water and Wastewater Company for assisting us in this research project.

\section{Ethics approval and consent to participate: waivers}

Consent for publication: Not applicable

Funding: This research was financially supported by grant no 407242 from the research council of Ferdowsi University of Mashhad. Mashhad, Iran.

Availability of data and material: The data that support the findings of this study are available from the corresponding author upon reasonable request.

Code availability: Not applicable

\section{References}


1. Behboudi, A., Y. Jafarzadeh, and R. Yegani, Polyvinyl chloride/polycarbonate blend ultrafiltration membranes for water treatment. Journal of membrane science, 2017. 534: p. 18-24. doi: 10.1016/j.memsci.2017.04.011

2. Salari, A., S. Khanzadi, and Z. Rezaei, Survey of Fluoride, Chlorine, Potassium, Sodium, and Trihalomethane contents in the drinking water of five major universities in Iran. Journal of Advances in Environmental Health Research, 2018. 6(4): p. 202-209.doi:

10.22102/JAEHR.2018.140528.1093.

3. Organization, W.H., Guidelines for drinking-water quality: second addendum. Vol. 1, Recommendations. 2008. https://apps.who.int/iris/handle/10665/204412

4. Özkara, A. and D. Akyıl, Environmental Pollution and Pollutants on the Ecosystem: A Review. Türk Bilimsel Derlemeler Dergisi, 2018. 11(2): $\mathrm{p}$. 11-17.

5. Tchounwou, P.B., et al., Heavy metal toxicity and the environment. Molecular, clinical and environmental toxicology, 2012: p. 133-164.

6. Salmani, M.H., H. Mozaffari-Khosravi, and Z. Rezaei, The nickel concentration in breast milk during the first month of lactation in Yazd, Center of Iran. Biological trace element research, 2016. 174(1): p. 65-70. 10.1007/s12011-016-0703-6

7. Mohod, C.V. and J. Dhote, Review of heavy metals in drinking water and their effect on human health. International Journal of Innovative Research in Science, Engineering and Technology, 2013. 2(7): p. 2992-2996.

8. Pirsaheb, M., R. Khamutian, and S. Pourhaghighat, Review of heavy metal concentrations in Iranian water resources. International Journal of Health and Life Sciences, 2015. 1(1): p. 35-45.

9. Salmani, M.H., et al., Arsenic exposure to breast-fed infants: contaminated breastfeeding in the first month of birth. Environmental Science and Pollution Research, 2018. 25(7): p. 6680-6684. 10.1007/s11356-017-0985-z

10. Organization, W.H., Arsenic in drinking-water: Background document for development of WHO guidelines for drinking-water quality. 2003, World Health Organization. https://apps.who.int/iris/handle/10665

11. Farhadkhani, M., et al., Assessment of drinking water quality from bottled water coolers. Iranian Journal of Public Health, $2014.43(5)$ : p. 674.

12. Sorlini, S., et al., Assessment of physical-chemical drinking water quality in the Logone Valley (Chad-Cameroon). Sustainability, 2013. 5(7): p. 3060-3076. 10.3390/su5073060.

13. Davoudi, M., et al., The investigation of chemical quality and stability indices of drinking water in rural areas of Taybad City in $2015-16$. Journal of Torbat Heydariyeh University of Medical Sciences, 2016. 4(2): p. 4-13.

14. Muthuraman, G. and S. Sasikala, Removal of turbidity from drinking water using natural coagulants. Journal of Industrial and Engineering Chemistry, 2014. 20(4): p. 1727-1731. 10.1016/j.jiec.2013.08.023.

15. Schwartz, J., R. Levin, and R. Goldstein, Drinking water turbidity and gastrointestinal illness in the elderly of Philadelphia. Journal of Epidemiology \& Community Health, 2000. 54(1): p. 45-51.

16. Owa, F., Water pollution: sources, effects, control and management. Mediterranean journal of social sciences, 2013. 4(8): p. 65-65. 10.5901/mjss.2013.v4n8p65.

17. Wimalawansa, S.J., Purification of contaminated water with reverse osmosis: effective solution of providing clean water for human needs in developing countries. International journal of emerging technology and advanced engineering, 2013. 3(12): p. 75-89.

18. UNICEF, Promotion of household water treatment and safe storage in UNICEF WASH programmes. Washington: UNICEF, 2008.

19. Kayaga, S. and B. Reed, Emergency treatment of drinking water at the point of use. World Health Organization, 2011.

20. Sadeghi, G., et al., Microbiological quality assessment of rural drinking water supplies in Iran. Journal of agriculture \& social sciences, 2007. 3(1): p. 31-33.

21. Ngari, M.S., et al., Physico-chemical properties of spring water in kabare and baragwi locations, Gichugu Division Kirinyaga County of Kenya. 2013.

22. Inui, T., et al., Determination of heavy metals at sub-ppb levels in water by graphite furnace atomic absorption spectrometry using a direct introduction technique after preconcentration with an iminodiacetate extraction disk. 2012. 10.4236/ajac.2012.310090 .

23. Gul, N., et al., Arsenic and heavy metals contamination, risk assessment and their source in drinking water of the Mardan District, Khyber Pakhtunkhwa, Pakistan. Journal of water and health, 2015. 13(4): p. 1073-1084.

24. Ma, K., et al., Role of typical pipes in disinfection chemistry within drinking water distribution system. Water Supply, 2021. 21(3): p. 1263-1276. $10.2166 /$ wh.2015.011

25. Bairagh, L.R. and F. Nasehi, Zoning release of heavy metals in the ground water of Karaj plains, Tehran. BIOSCIENCE BIOTECHNOLOGY RESEARCH COMMUNICATIONS, 2016. 9(2): p. 253-261. 10.21786/bbrc/9.2/11.

26. Ghaderpoori, M., et al., Health risk assessment of fluoride in water distribution network of Mashhad, Iran. Human and Ecological Risk Assessment: An International Journal, 2019. 25(4): p. 851-862. 10.1080/10807039.2018.1453297.

27. Peiravi, R., et al., Heavy metals concentrations in Mashhad drinking water network. Zahedan Journal of Research in Medical Sciences, 2013. 15(9): p. 74-76. 
28. Velayatzadeh, M. and K. Payandeh, Effect of household water treatment on the concentration of heavy metals of drinking water in Ahvaz city. ISMJ, 2020. 22(6): p. 402-414.

29. Sagle, A. and B. Freeman, Fundamentals of membranes for water treatment. The future of desalination in Texas, $2004.2(363)$ : p. 137.

30. Mintz, E.D., F.M. Reiff, and R.V. Tauxe, Safe water treatment and storage in the home: a practical new strategy to prevent waterborne disease. Jama, 1995. 273(12): p. 948-953. 10.1001/jama.1995.03520360062040

31. Ghaderpoori, M., Heavy metals analysis and quality assessment in drinking water-Khorramabad city, Iran. Data in brief, 2018.16 : p. 685. 10.1016/j.dib.2017.11.078.

\section{Figures}

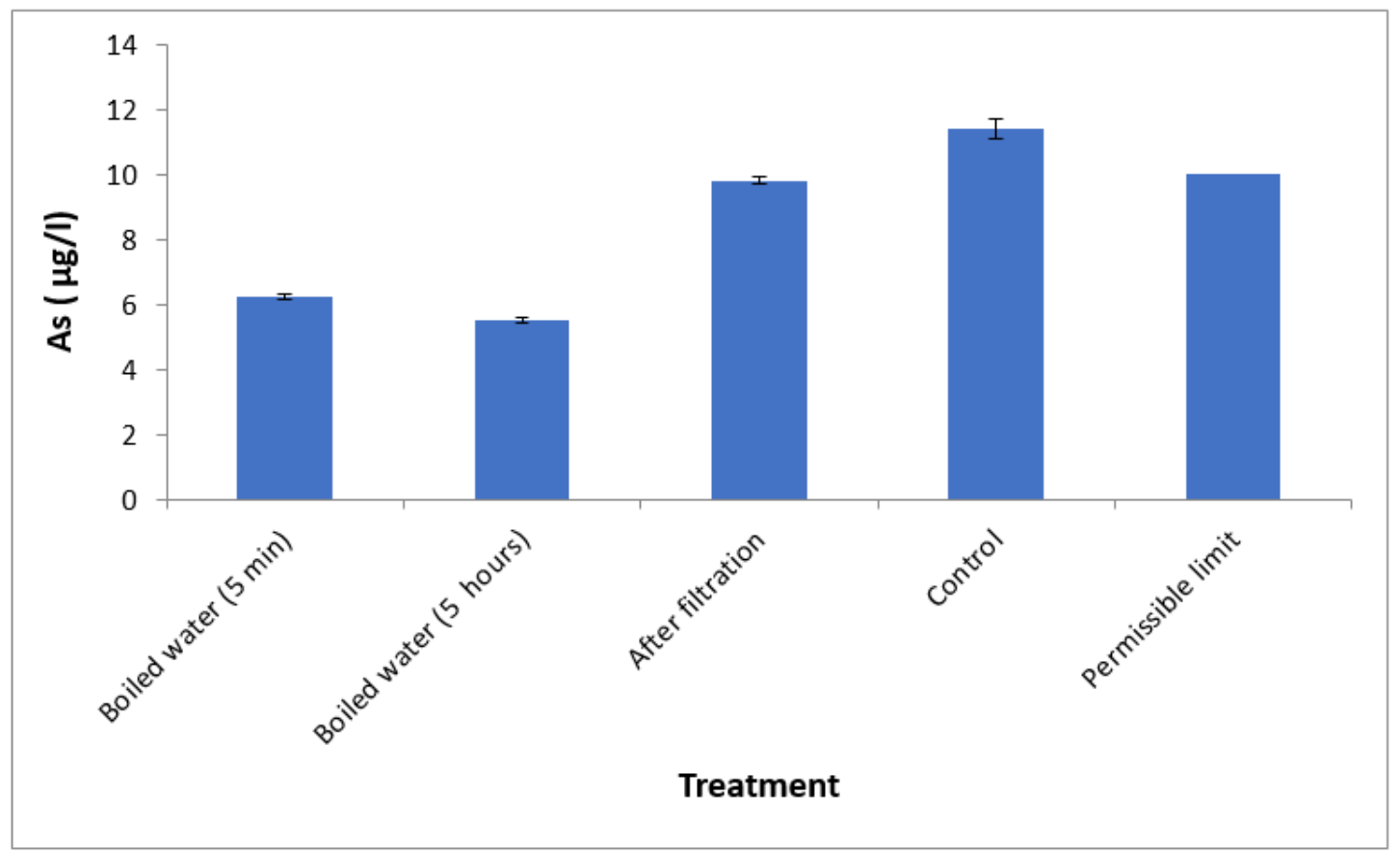

Figure 1

Effect of refin processes $r$ on arsenic content level

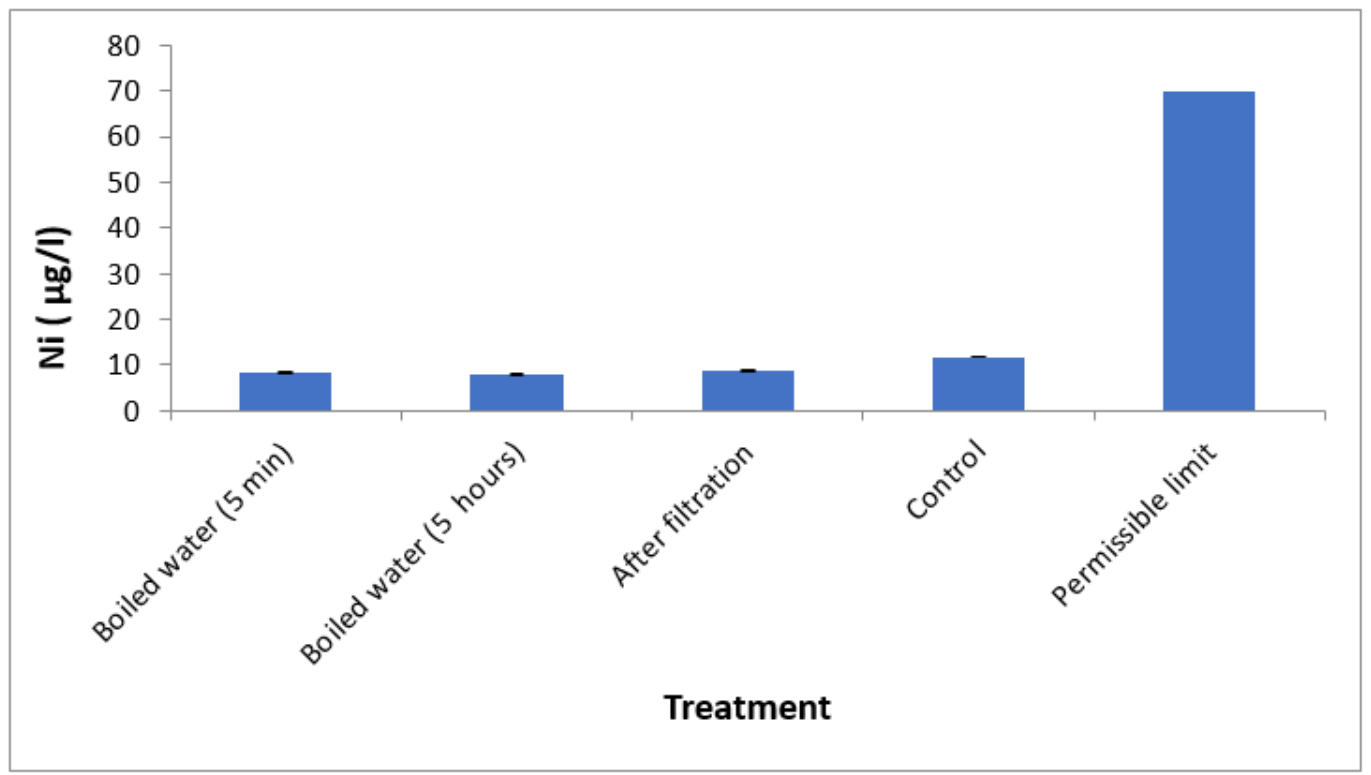

Figure 2 


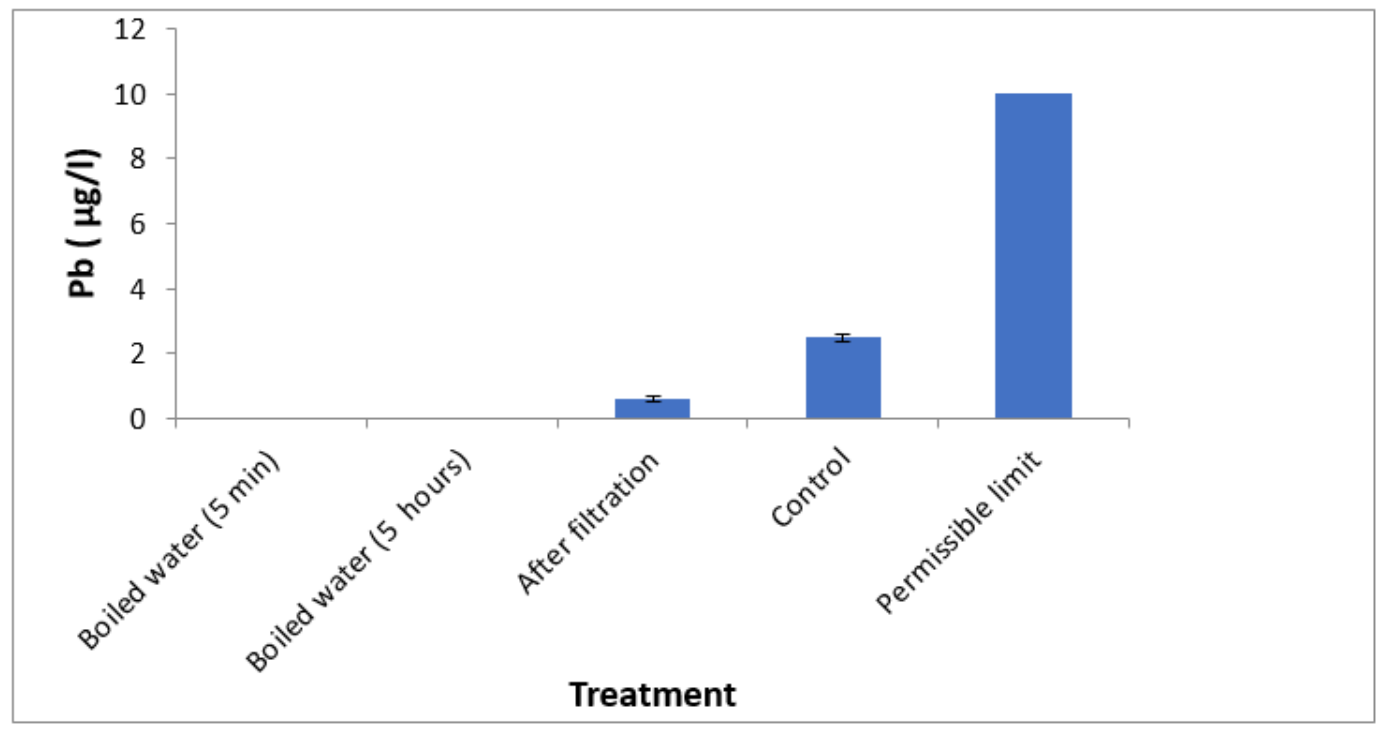

\section{Figure 3}

\section{Effect of refin processes on lead content level}

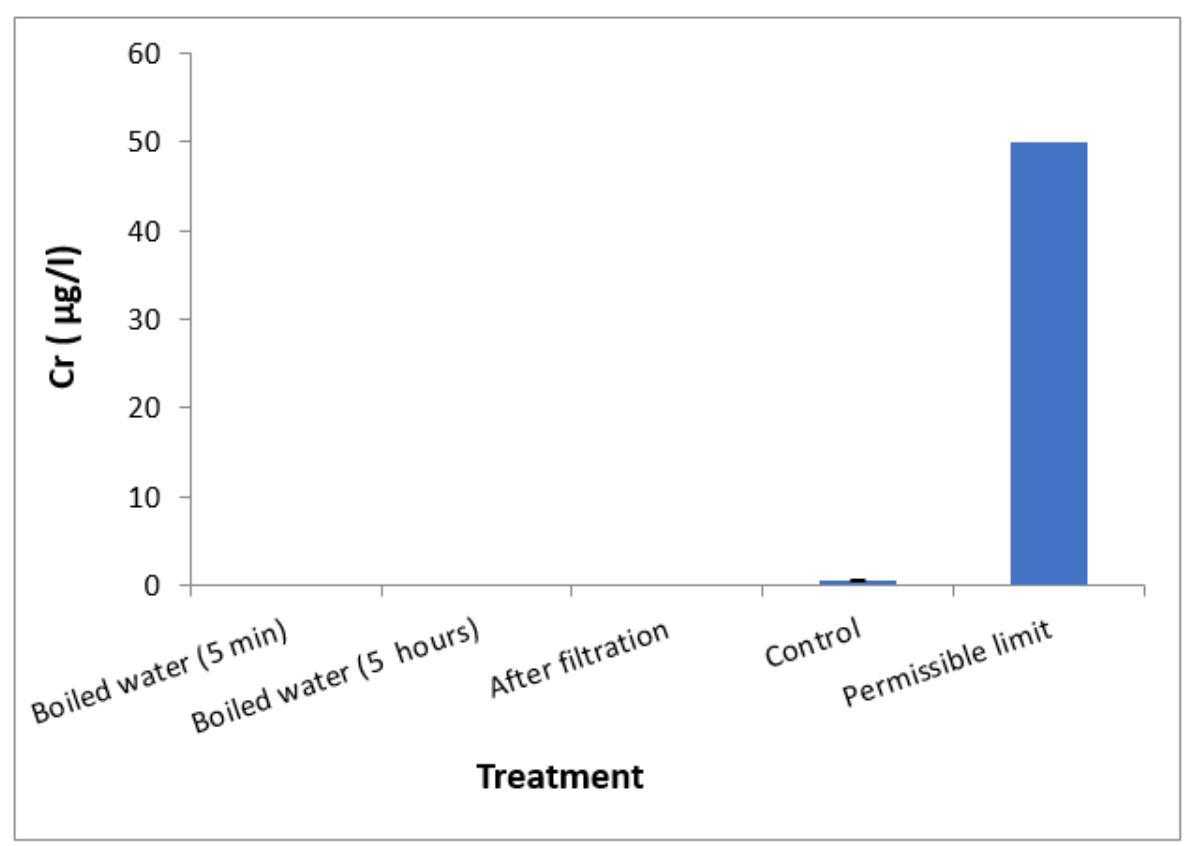

Figure 4

Effect of refin processes on Chromium content level 


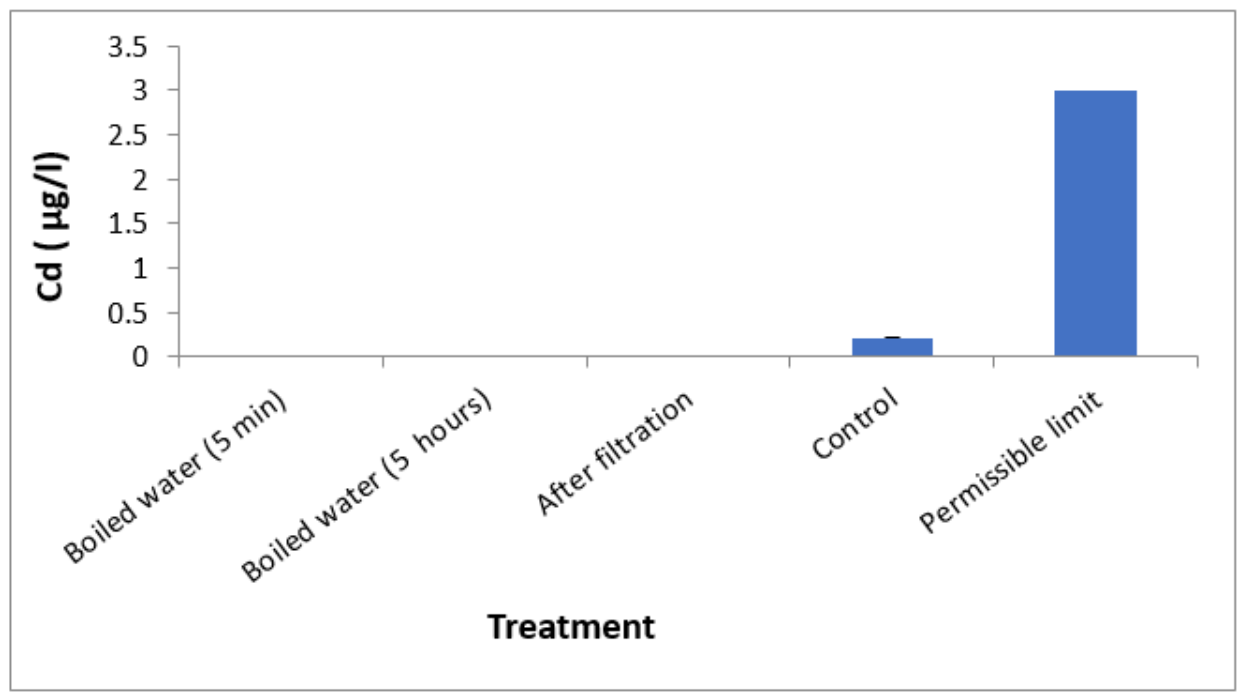

Figure 5

Effect of refin processes on Cadmium content level 